\title{
'N ELEKTROMIOGRAFIESE ANALISE VAN DIE LIPFUNKSIES VAN DIE GESPLETE LIP-GEVAL
}

\author{
WILMA UYS B.A. (LOG.) (PRETORIA) \\ Spraak-, Stem-en Gehoorkliniek Universiteit van Pretoria
}

\section{OPSOMMING}

'n Elektromiografiese analise van die lipfunksies van 'n groep gesplete lipgevalle, is vergelyk met dié van 'n groep sonder so 'n strukturele af wyking.

Die toetsmateriaal het basiese bewegings van die lippe wat onderliggend is aan die bemeestering van labiale en labiodentale artikulasie, asook die uitvoering van sodanige artikulatoriese bewegings, beslaan.

Nadat syferwaardes aan die kwalitatiewe evaluasie (volgens die skaal van Basmajian) geheg is, kon rekenkundige gemiddeldes verkry word. Hieruit blyk dit dat die eksperimentele groep minder spierspanning vertoon in die uitvoering van lipfunksies as die kontrole groep. Omdat daar geen grense vir normaliteit bestaan nie, kan die mate van spanning egter nie as afwykend beskou word nie. Leidrade vir terapie kan uit dié analise verkry word en ook 'n moontlike maatstaf vir objektiewe beoordeling van die geslaagdheid van die operasietegnieke.

\section{SUMMARY}

A comparison between the electro-myographic analysis of lip functions of speakers with a cleft lip and speakers with a normal structure, is presented. Lip movements associated with labial and labiodental articulation were studied, as well as performance of these articulatory movements. Numeric values were awarded to qualitative evaluations (according to the scale of Basmajian) in order to compute mean values.

Results indicate that, for the experimental group, less tension was present during the execution of lip functions. As the range of normal tension has not yet been established, however this cannot be regarded as defective.

Certain suggestions for therapy can be drawn from this analysis, as well as a possible criterion for judging the effectiveness of surgical techniques.

Die toestand van gesplete lip is baie afgeskeep in die Spraakheelkúnde, moontlik omdat ondersoekers meen dat die spraak van so 'n pasiënt baie selde beinvloed word.

Hierdie aanname word bloot gemaak op die akoestiese resultaat van die spreker, wat 'n subjektiewe evaluasie is, a'angesien die mens as beoordelaar optree en spraak beoordeel in terme van dit wat hy hoor ${ }^{3,7}$

By die gesplete lip is dit hoofsaaklik die m. orbicularis oris, maar ook bloedvat- en senuweebaanverloop wat struktureel beinvloed is. ${ }^{5}$ Deur operasies word die spleet herstel en daar word aanvaar dat daar dan funksioneel geen 
afwyking aanwesig sal wees nie. Daar bestaan dus in die Spraakheelkunde 'n versuim om vas te stel of die funksies van hierdie lip werklik normaal is objektief-wetenskaplik gemeet. Is die operasie geslaagd? Vind daar kompensatoriese werking plaas wat op die oog af nie waarneembaar is nie? Kwalitatiewe afleidings behoort slegs gemaak te word, indien.dit deur kwantitatiewe gegewens gestaaf kan word. Die resultate verkry uit elektromiografie voldoen aan hierdie vereistes.

Om genoemde vrae te beantwoord, moet twee aspekte getoets word. Primêr moet die hoeveelheid spierspanning wat deur die aktiwiteit benodig word, bepaal word, en sekondêr die senuwee-innervering wat aktiwiteit moontlik maak. Elektromiografie is 'n ondersoekmetode wat uniek is in dié opsig dat dit presies openbaar wat 'n spier doen op enige gegewe oomblik tydens enige beweging, ${ }^{1}$ omdat dit die elektriese potensiaal wat opgewek word tydens aktiwiteit, registreer. ${ }^{4}$

\section{METODE}

Die doel van die studie was om die lipfunksies van die gesplete lip-geval te vergelyk met dié van die normale en sodoende vas te stel:

a) of die lipfunksies ooreenstem met dié van die normale;

b) of kompensatoriese werking ingetree het;

c) of die operasietegniek geslaagd is;

d) en hoe uit hierdie resultate, leidrade t.o.v. terapie verkry kan word.

Daar word gehipotetiseer dat die gesplete lip-geval minder spierspanning as die normale sal vertoon by die uitvoering van lipfunksies. Die strukturele afwyking van die gesplete lip word as rede hiervoor aangevoor, ${ }^{5,6}$

Proefpersone Vier vroulike proefpersone is geselekteer deur die metode van afgepaarde vergelyking. Twee proefpersone is 11 jaar oud (een kontrole-en een eksperimentele proefpersoon) en twee is 19 jaar (een kontrole- en een eksperimentele proefpersoon). Die teenwoordiging van 'n gesplete lip het die eksperimentele groep van die kontrolegroep geskei. Die volgende faktore is konstant gehou.

Taal Al die proefpersone is Afrikaanssprekend omdat daar 'n artikulasiebasis. verskil tussen Afrikaans en Engels bestaan.

Gehoor Suiwertoon-luggeleidingsoudiogramme toon aan dat al vier proefpersone normale gehoor het.

Intelligensie Van die klasonderwyseres is verneem dat die 11 -jarige proefpersone ' $n$ bogemiddelde intelligensie het en die aanname is gemaak dat universiteitstudente 'n bogemiddelde intelligensie het.

Artikulasie Die geoefende oordeel van finalejaar B.A. (Log.)-studente is gebruik om die proefpersone se artikulasie te beoordeel. Geen artikulasie-

- afwyking is teenwoordig nie.

Tipe lipspleet 'n Unilaterale spleet aan die linkerkant is by albei proefpersone van die eksperimentele groep teenwoordig en strek vanaf die inferior-grens van die bo-lip tot by die neusholte. 
Operasies Slegs een operasie ter herstelling van die gesplete lip is uitgevoer op elk van die proefpersone van die eksperimentele groep terwyl hulle nog babas was. Op die een is 'n sekondêre operasie uitgevoer om die volheid van die bo-lip te verbeter. Hierdie operasie is reeds twee jaar gelede uitgevoer. (De Palma et al het d.m.v. 'n elektromiografiese studie vasgestel dat die motoreenheid ná so 'n operasie binne 21 maande regenereer en dat reīnnervering weer plaasvind.) ${ }^{2}$ Weens onvermydelike omstandighede kon die operasietegnieke wat gebruik is, nie vasgestel word nie.

Terapie Proefpersone van die eksperimentele groep het nooit terapie ter verbetering van die lipfunksies ontvang nie.

Toetsmateriaal Drie tipes toetsmateriaal is voorgeskryf.

1. Basiese bewegings van die lippe wat onderliggend aan die bemeestering van labiale artikulasie is, bv., tuit en strek van die lippe en die trek van die mondhoeke afsonderlik na die onderskeie kante toe.

2. Die vinnige sluiting en opening van die lippe deur die konsonant $/ \mathrm{p} /$ vir 5 sekondes lank so vinnig as moontlik te herhaal. Dit dien as waarborg vir die bemeestering van labiale artikulasie.

3. 'n Woordlys is opgestel wat bilabiale en labiodentale klanke in anlaut-, inlaut- en auslaut-posisies bevat het en al die vokale van Afrikaans in inlaut. of auslaut-posisie. Die woordlys is opgestel om die voorkomsfrekwensie van die klanke konstant te hou, koartikulasie sover as moontlik uit te skakel en om kort response aan te teken op die elektromiogramme sodat die evaluasie daarvan vergemaklik kon word.

'n Disa-driekanaal elektromiograaf is gebruik met oppervlakte elektrodes wat uit silwer vervaardig is. Die elektrodes het ' $n$ deursnee van $2 \mathrm{~mm}$. sodat dit lig is en gevolglik nie lipbewegings bemoeilik nie. Elektrode-jellie is gebruik om elektriese kontak te verseker en die elektrodes is met kleefband op die vel vasgeheg. 'n Stophorlosie is gebruik om die 5 sekondes van $/ p /$ herhaling af te tel.

Die gronddraad is om die proefpersoon se arm gebind, en die twee elektrodes is eers op die bo-lip, aan weerskante van die filtrum geplaas en daarna op die onder-lip aan weerskante van die middellyn daarvan. Met ander-woorde, die . elektrodes is op die $\mathrm{m}$. orbicularis oris geplaas wat ná aan die oppervlakte geleë is en dus nie 'n naaldelektrode benodig nie. Slegs die m. orbicularis oris word by die eksperiment betrek, omdat dit hierdie spier is wat struktureel beïnvloed is deur 'n gesplete lip.

By die analise van die elektromiogramme is die skaal van Basmajian' gebruik. Hierdie skaal gee 'n kwalitatiewe interprețasie t.o.v. die hoeveelheid aktiwiteit aanwesig, nl., geen, waarneembaar, gering; gemiddeld, uitgesproke en baie uitgesproke. ${ }^{1}$ Om statistiese verwerkings hieruit moontlik te maak, is syferwaardes vanaf 0 tot 5 in hierdie volgorde onderskeidelik aan die genoemde waardebepalings toegesê.

Al die toetsitems is geklassifiseer onder die batterye ,gerond”, „ontrond", „,neutraal”, „bilabiaal”, „labiodentaal” en ',rigtings”, sodat dieselfde lipbewegings saam beoordeel sou word. 


\section{RESULTATE}

Rekenkundige gemiddeldes is verkry en die volgende aspekte is vergelyk:

Proefpersone teenoor batterye. Eksperimentele groep teenoor kontrolegroep. Battery teenoor battery. Proefpersoon teenoor proefpersoon.

Uit die syfergegewens blyk dit dat die kontrolegroep vir al die batterye meer aktiwiteit in die onder-lip as in die bo-lip vertoon in teenstelling met die eksperimentele groep. Ook vir die batterye: ,gerond”, „labiodentaal" en „rigtings" vertoon die kontrolegroep meer aktiwiteit in die bo-lip as in die onder-lip in teenstelling met die eksperimentele groep. Vir die ander drie batterye is die teenoorgestelde waar.

Die volgorde waarin die batterye geplaas kan word in terme van die hoeveelheid aktiwiteit benodig, is soos volg:

a) ,gerond", met die bo-lip die mees aktiewe;

b) „labiodentaal", met die bo-lip die mees aktiewe;

c) „ontrond", met die onder-lip die mees aktiewe;

d) "bilabiaal", met die onder-lip die mees aktiewe;

e) „neutraal", met die bo-lip die mees aktiewe; en

f) „rigtings", met albei lippe ewe aktief, aangesien die spiere van die hoek van die mond dié werking veroorsaak.

\begin{tabular}{|lccc|}
\hline & Bo-lip & Onder-lip & Gesamentlik \\
Kontrolegroep & 3,24 & 4,07 & 3,66 \\
Eksperimentele groep & 2,9 & 1,99 & 2,45 \\
\hline
\end{tabular}

Tabel I - Rekenkundige gemiddeldes verkry van totale hoeveelheid spierspanning.

Hieruit kan dus afgelei word dat die kontrolegroep meer van die onder-lip as van die bo-lip gebruik maak, terwyl die eksperimentele groep meer van die bo-lip as van die onder-lip gebruik mak. Uit die laaste kolom blyk dit dat die aanvanklike hipotese aanvaar kan word - die eksperimentele groep vertoon minder spierspanning tydens lipfunksionering.

\section{AFLEIDINGS}

Ten opsigte van die operasietegnieke wat op die twee proefpersone gebruik is, blyk die operasietegniek van die jonger proefpersoon meer suksesvol te wees. Die verskil tussen die gemiddelde hoeveelheid aktiwiteit van die lippe van die twee jonger proefpersone is minder as die verskil tussen die twee ouer proefpersone.

Die bo-lip van die eksperimentele groep gebruik skynbaar meer aktiwiteit om te kompenseer vir die strukturele afwyking. Daar moet dus in terapie gepoog word om die bo-lip meer aktief te kry, sonder dat inspanning gebruik word. 
Die aandeel van die onder-lip in labiale artikulasie moet vergroot word sodat die verhouding tussen bo. en onder-lip nader aan die normale gebring word.

Daar kan egter nie beweer word dat hierdie spanning wat die gesplete lip-geval vertoon, afwykend is nie, aangesien daar geen grense vir normaliteit bestaan nie, en die kompensatoriese werking van die omliggende spiere nie bekend is nie.

Daar moet dus 'n studie gedoen word om al die spiere betrokke by artikulasie te oridersoek en norme vas te stel. Slegs dan kan spierwerking as afwykend bestempel word en kan die mate van kompensatoriese werking van ander spiere bepaal word.

Elektromiografie leen hom ook tot studies waar koartikulasie bepaal moet word en dit kan met vrug hiervoor aangewend word.

\section{BIBLIOGRAFIE}

1. Basmajian, J.V. (1962): Muscles Alive. Their functions revealed by electromyography. The Williams and Wilkens Company, Baltimore.

2. De Palma, A.P., Leavitt, L.A., Hardy, S.B. (1958): Electromyography in full thickness flaps rotated between upper and lower lips. Plastic and Reconstructive Surgery, 21, 448-452.

3. Drillien, C.M., Ingram., T.T.S., Wilkenson, E.M. (1966): The causes and natural history of cleft lip and palate. E. and S. Livingstone Ltd., Edinburgh.

4. Fromkin, V.A. (1963): Some phonetic specifications of linguistic units: an electromyographic investigation. Working Papers in Phonetics. 3, 1-170.

5. Pennisi, V.R., Shadish, W.R., Klabunde, E.H. (1969): Orbicularis oris muscle in cleft lip repair. Cleft Palate Journal, 6, 141-153.

6. Slaughter, W.B., Henry, J.W., Berger, J.W., Berger, J.C. (1960): Changes in blood vessel patterns in bilateral cleft lip. Plastic and Reconstructive Surgery, 26, 166-179.

7. Spriestersbach, D.C., Powers, G.R. (1959): Articulation skills, velopharyngeal closure and oral breath pressure of children with cleft palates. J.S.H.R., 2, 318-325. 